First Peoples Child \& Family Review

An Interdisciplinary Journal Honouring the Voices, Perspectives, and Knowledges of

First Peoples through Research, Critical Analyses, Stories, Standpoints and Media

Reviews

\title{
Irihapeti Ramsden: The Public Narrative on Cultural Safety
}

\section{Steve Koptie}

Volume 4, Number 2, 2009

URI: https://id.erudit.org/iderudit/1069328ar

DOI: https://doi.org/10.7202/1069328ar

See table of contents

\section{Publisher(s)}

First Nations Child and Family Caring Society of Canada

\section{ISSN}

1708-489X (print)

2293-6610 (digital)

Explore this journal

Cite this article

Koptie, S. (2009). Irihapeti Ramsden: The Public Narrative on Cultural Safety. First Peoples Child \& Family Review, 4(2), 30-43.

https://doi.org/10.7202/1069328ar

\section{Article abstract}

The magnificent voices of Indigenous women who want to restore, preserve and extend the beauty of Indigenous culture must be relocated and honoured as the last best hope of escaping the tragic impacts of colonization. This paper started as an exploration of New Zealand Indigenous scholar Irihapeti Ramsden's extraordinary efforts to imbed Cultural Safety as a foundation for nursing training and unity of purpose for all community helpers to alter the trajectory of colonization and its tragic impacts on Indigenous peoples. It morphed into a celebration of the powerful 'reflective topical auto-biographies' or meta-narratives of adaptability and resilience all Indigenous people need to share as we recover and heal from intergenerational traumas inflicted in the name of civilization and racial supremacy. Transformative change starts with self discovery as Irihapeti Ramsden taught her student nurses. Women and children are the most poignant victims of that foolish colonial project and their survival stories can lead all humanity back to respectful and loving sustainability. Indigenous women's resilience stories need a special space in academic literature. Their enduring women-spirit has always guided this First Nations to be better first as an Indigenous man and more importantly as a human being. Irihapeti Ramsden's journey to put Cultural Safety out there in mainstream academia began with a powerful reflective inner healing journey. Her life and work was a remarkable gift to all. The title of this paper derives from Section Three of her PhD thesis. It must be shared throughout all the worlds' spaces in need of decolonization. Her ultimately political meta-narrative to alter ignorance and arrogance within education, government and society is one all Indigenous writers and scholars must study and articulate across often culturally unsafe places and spaces within Canada's colleges and universities.
This document is protected by copyright law. Use of the services of Érudit (including reproduction) is subject to its terms and conditions, which can be viewed online.

https://apropos.erudit.org/en/users/policy-on-use/ 


\title{
INitest Peoples Child \& Samily Review
}

An Interdisciplinary Journal Honoring the Voices, Perspectives and Knowledges of First Peoples through Research, Critical Analyses, Stories, Standpoints and Media Reviews

\section{Irihapeti Ramsden: The Public Narrative on Cultural Safety}

\author{
Steve Koptie
}

${ }^{a}$ M.Ed Student, University of Toronto, Toronto, Ontario, Canada.

\begin{abstract}
Although the daughter of an historian I had little knowledge of the political history or the legislative manipulation of the ownership of Maori land and the social, economic, educational and legislative processes, which led to the poverty of Maori people .... I did not understand why Maori were stereotyped as unintelligent, irresponsible and lazy. Why Maori were demonized in the media, filled the prisons and hospitals and were told that they had the same opportunities for successful social accomplishment as everyone else. My whole experience showed me that there were fundamental and brutal injustices in our society and I wanted to know how and why they got there, how they worked and how they were sustained (Irihapeti Ramsden, 2003).
\end{abstract}

\section{Introduction}

This paper started as an examination of the concept of Cultural Safety and the need to adopt imaginative cross-cultural approaches to recovery in Indigenous communities (Ramsden, 2003). Sometimes Indigenous scholars write research papers that morph into transcendental and transformative journeys of reclamation and recovery of our distinct ancestral voice. In this instance, the narrative did become such a selfreflective personal locating process. A search for the initiation of the concept of "Cultural Safety" became a loving celebration of the amazing role models and mentors, especially women, who nurtured and directed my community healing work. Irihapeti Ramsden's

Questions or correspondence concerning this article may be addressed to:

$$
\text { koptie.steven@gmail.com }
$$

\begin{abstract}
The magnificent voices of Indigenous women who want to restore, preserve and extend the beauty of Indigenous culture must be relocated and honoured as the last best hope of escaping the tragic impacts of colonization. This paper started as an exploration of New Zealand Indigenous scholar Irihapeti Ramsden's extraordinary efforts to imbed Cultural Safety as a foundation for nursing training and unity of purpose for all community helpers to alter the trajectory of colonization and its tragic impacts on Indigenous peoples. It morphed into a celebration of the powerful 'reflective topical autobiographies' or meta-narratives of adaptability and resilience all Indigenous people need to share as we recover and heal from intergenerational traumas inflicted in the name of civilization and racial supremacy. Transformative change starts with self discovery as Irihapeti Ramsden taught her student nurses. Women and children are the most poignant victims of that foolish colonial project and their survival stories can lead all humanity back to respectful and loving sustainability. Indigenous women's resilience stories need a special space in academic literature. Their enduring women-spirit has always guided this First Nations man to be better first as an Indigenous man and more importantly as a human being. Irihapeti Ramsden's journey to put Cultural Safety out there in mainstream academia began with a powerful reflective inner healing journey. Her life and work was a remarkable gift to all. The title of this paper derives from Section Three of her PhD thesis. It must be shared throughout all the worlds' spaces in need of decolonization. Her ultimately political meta-narrative to alter ignorance and arrogance within education, government and society is one all Indigenous writers and scholars must study and articulate across often culturally unsafe places and spaces within Canada's colleges and universities.
\end{abstract}

efforts conjured up a deep appreciation for the strong women-spirit put in place to fight for the protection of cultural integrity in many Indigenous spaces. Dr. Irihapeti Ramsden belonged to the people of Ngai Tahupotiki and Rangitane or if expressed in colonial identity markers, she was a Maori woman of Aotearoa, New Zealand. 
Her 2003 Ph.D. thesis has become a reference point for Indigenous peoples around the globe struggling to locate their identity and to have it properly reflected in the mainstream/dominant culture, academia, and health and social services. Her thesis was completed just ahead of her death at age 57 after a 5-year battle with breast cancer. Irihapeti Ramsden influenced the training of nurses and midwives in her homeland and through her ground breaking work it became mandatory that a Cultural Safety curriculum would constitute $20 \%$ of Zealand nursing and midwifery courses. State examinations for all nurses and midwives were held to standards set in the above descriptions. These principles also initiated an important dialogue within her homeland on workforce development and intellectual property rights, and continue today to impact all international nurses associations. This increasing awareness highlights the heroic achievements of Irihapeti Ramsden's Indigenous women-spirit.

From 1992, when Irihapeti Ramsden introduced the concept of Cultural Safety into the nursing academic literature, an evolutionary movement sprang from cultural awareness, cultural sensitivity, and culminated in a Cultural Safety education requirement for all New Zealand nurses. The movement shifted the paradigm of service, and Irihapeti Ramsden (2003) expressed Cultural Safety as:

The process towards achieving Cultural Safety in nursing and midwifery practice can be seen as a step-wise progression from cultural awareness through to cultural sensitivity and on to Cultural Safety. However, the terms cultural awareness and cultural sensitivity are not interchangeable with Cultural Safety. These are separate concepts:

CULTURAL SAFETY is an outcome of nursing and midwifery education that enables safe service to be defined by those that receive the service.

CULTURAL SENSITIVITY alerts students to the legitimacy of difference and begins a process of self-exploration as the powerful bearers of their own life experience and realities and the impact this may have on others.

CULTURAL AWARENESS is a beginning step towards understanding that there is difference. Many people undergo courses designed to sensitize them to formal ritual rather than the emotional, social, economic and political content in which people exist (Ramsden, 1992a) (Ramsden, 2003, p.116).

A student mentored by Irihapeti Ramsden, Lis Ellison-Loschmann (2003) wrote in an obituary in the British Medical Journal that Irihapeti Ramsden's legacy was bringing Maori health disparities to public consciousness and marking them as indicators of historical, social, economic, and political colonial upheavals. Ellison-Loschmann (2003) reminds proponents of Cultural Safety that Irihapeti Ramsden "calmly and eloquently responded to misrepresentations and accusations about the aims of Cultural Safety, which in the end, allowed for paradigm shift and the beginning of the de-colonization of New Zealand. I. M. Ramsden (2003) would inspire a framework from which Indigenous scholars could explore and express the impacts of colonization on Maori people. She cautioned Indigenous writers and thinkers to first contextualize their ancestors struggle for "change in a climate of colonially inherited institutional racism" (Ellison-Loschmann, 2003). EllisonLoshmann (2003) in her obituary for Irihapeti Ramsden shared a reflective narrative of an opening statement Irihapeti Ramsden made at a lecture in 2001. Irihapeti Ramsden challenged the nurse trainees: "there are three kinds of people; those who make things happen, those who watch things happen and those who never knew what hit them-let nurses be in the first category" (Ellison-Loshmann, 2003). This is the true essence of women-spirit, something and someone that nurtures and empowers all who envision a better world for all. Indigenous women have carried in their blood memories, according to Jan Longboat (2009), the teachings and values to live a good and balanced life.

Recently I spent a week at the first Indigenous Graduate student writing retreat held by the Supporting Aboriginal Graduate Enhancement (SAGE) group in March 2009 on Lake Simcoe, Ontario. The SAGE initiative follows the model for increasing the professional workforce development of Indigenous peoples created in New Zealand as a result of Irihapeti Ramsden's legacy. The University of Toronto SAGE group mentored by Canadian Indigenous scholar Dr. Jean-Paul Restoule seeks

\section{Acknowledgements:}

It is one thing to consider great thoughts but as most Indigenous men the requirement to listen deeply to the words of women with enduring woman-spirit restores the magic of our ancestors' intentions. I want to graciously extend the warmest possible admiration and appreciation to the women who guide my work. This paper was only possible by the guidance of Indigenous women such as Dr. Cynthia Wesley-Esquimaux, Dr. Suzanne Stewart, Lee Maracle, Jan Longboat, Pauline Shirt and fellow graduate student Ashley Quinn whose women-spirit is generously shared as Irihapeti Ramsden's life work highlights. A special expression of gratitude for creative nurturance goes to Dr. Sharon Sbrocchi who courageously teaches with Cultural Safety embedded pedagogy. That is another paper. Indigenous scholars thrive with such powerful role-models, mentors and allies. 
to recruit, and promote higher education and Cultural Safety within Canadian universities in order to create a vibrant professional knowledge and skills transfer to and from Indigenous communities. The SAGE writing retreat was guided by renowned Indigenous author Lee Maracle and Cree Elder Pauline Shirt. Their deeply embedded grace, generosity, compassion, kindness and patience expressed through their nurturing women-spirit reinforced, for me, the strength of natural Indigenous resilience in the face of oppression and Euro-centric misunderstandings and misconceptions that threaten harmony on Mother Earth. Lee Maracle and Pauline Shirt (2009) spun webs of spell binding stories and narratives to explore and root out the "pathos" of colonization that created the trajectory of pathology we struggle within our families, communities and nations. Lee Maracle (2009) inspired the group to write from a place of spiritual desire in order to reclaim the resilience bequeathed from ancestral legacies we still carry in spite of the colonial siege we have endured and survived. Too much focus on pathology according to Lee Maracle distracts us from our abilities to think deeply, to ponder, to wonder, and to connect with all Creation. We can call on the wisdom of generations of demonstrated and remarkable resilience, and formulate creative life-ways to prepare future generations for good lives and ecological harmony. Our enduring gift to humanity, according to Pauline Shirt (2009), is a cultural imperative to seek out higher levels of consciousness so that we can instruct on engaging Turtle Island [North America] sensibilities based on goodness for all, without harm. The womenspirit Irihapeti Ramsden, Lee Maracle, Pauline Shirt, Jan Longboat and many of this author's mentors represent the promise of a restoration of resilience that will heal all humanity. This is especially true when articulated through their Reflective Topical Autobiographies (Ramsden, 2003:7). They invite their students to explore and express goodness from the Seven Traditional Values: Courage, Honesty, Humility, Respect, Truth, Love, and Wisdom. Indigenous writers can imbed these values within academic literature as a Indigenous road map to decolonization. Knowing a narrative or teaching from each of those values is path-way to knowing the intentionality of our ancestors to remain with us. This author pleads all Indigenous scholars to meditate on the beautiful synergy in Section Three of Irihapeti Ramsden's doctorate thesis. At one point in study for this paper I found myself weeping with enlightenment on my personal journey to make sense of the historical impacts of my ancestors' legacy on my own life.

Irihapeti Ramsden spoke in terms of neo-colonial attitudes, believing that New Zealand had not yet reached the maturity or reconciled the longstanding harm their colonial systems brought to a naturally sovereign people. The dilemma for Indigenous scholars is how to articulate colonial interactions in all spheres of engagement that trap First Nations citizens in their traditional homelands within debilitating power imbalances. This longstanding dilemma of inequity makes notions of post-colonial collaboration and reconciliation premature. This author would suggest that Canadian Indigenous scholars face the equivalent frustration in educating our peers on the significance of this power imbalance. Irihapeti Ramsden (2003) quotes a friend and colleague Maori lawyer and expert on legal fights on Maori human rights, Moana Jackson;
The key to Cultural Safety for me is it part of making our people strong again and protecting our people where ever they are. And inventing a concept of Cultural Safety I think you've given our people a tool and although I didn't know much at the time of it's nursing ramifications, I could see it's value as a...if you like, a cementing tool, in the development of our people, and that's the effect it had on me...It had to develop in a particular context in nursing therefore it had all sorts of professional and nursing consequences. But it also had a much wider ramification that our people could use the idea of being culturally safe as part of their reclaiming of our sovereignty, of our rights and so on ... because for me, you can't claim rights unless you're safe and then have the power to do so. (Ramsden 2003 thesis chapter 9:1)

Irihapeti Ramsden has contextualized for all future Indigenous scholars and thinkers the experience of colonization and the resultant cultural and economic poverty she witnessed within her people in their ancestral homelands. This paper expands her powerful narrative, with concepts of Cultural Safety and reflective topical autobiography as honouring healing women-spirit in resistance to the oppression, sexism, racism and marginalization that came with colonization and the destruction of Indigenous life-ways and world views. It is the arduous journey from victim to survivor to victor (Wesley-Esquimaux, 2009) that Irihapeti Ramsden exemplifies in her narratives. Canada is in conflict with its Indigenous people in most areas of social, political, cultural and economic engagement and must provide safe spaces for the academic and bureaucratic transformation to occur. Cultural change is necessary to alter the trajectory of suffering of Indigenous peoples worldwide. The dependence wrought through state control of Indigenous homelands, just to facilitate the plundering of wealth and resources is now globally recognized, as indicated by the adoption of a framework for Indigenous Human Rights at the United Nations, from which Canada hides. This is a modern struggle of attrition where poverty and marginalization become the bureaucratic weapons to force Indigenous people off their resource rich lands. Forced cultural assimilation, 
and integration into a culturally unsafe and unreceptive mainstream milieus is leading more and more to uncover the image of unsustainable, destructive and unjust exploitation, especially in the vast boreal forest and northern land mass known as "Indian Country" (Koptie, 2009). While presenting at a Spirituality and Social Work Conference (2008) in Fredericton, New Brunswick, I was asked to comment on "Third World" conditions on Canada's remote reserves. I cautioned the group to reflect on the truth of that common mis-representation of Indigenous living conditions. To compare Canada's First Nations as a Third World confirms the perception of Canadian global indifference and complicity in the negative mining, forestry and resource plunder conducted in places no one sees or seems to care about to maintain privilege for mostly southern Canada. Canadian's are not innocent to the global wrongs of those who act on their behalf to sustain those privileges who disregard rights and responsibilities to preserve a living planet for future generations. Where does Canada find the moral imperative to challenge international violations to human rights yet justify by its silence at home the loss of human rights it refuses to provide to Indigenous peoples within its own backyard? Should the First Peoples of Canada remain captive to historic injustices kept just out of sight, victims of foolish and failed colonial policies just for political expediency and inequitable wealth generation? Constant media representations of drunken, lazy Indians dependent on tax payers' generosity belie the one-sided greed and selfishness of colonization (Koptie, 2009).

Indigenous scholars must emulate Irihapeti Ramsden's journey of enlightenment and help articulate how legislation like the Canadian Indian Act legitimized colonization of a naturally sovereign people (Longboat, 2009). The strained relations between Canadians and Indigenous people will not survive $21^{\text {st }}$ century sensitivities to social justice. We need to ensure the prevention of dangerous political, social, environmental and religious upheavals that threaten global well-being. Irihapeti Ramsden became a path-finder in finding ways to empower future generations to challenge the status quo that endorses indifferent or dismissive attitudes on human responsibility, she demanded that we learn to respect and accommodate the diversity of humanity. She taught her students to resist and rebel against the ignorance and arrogance of the settlers of New Zealand that continues to prevent deep soul searching of privileged colonizers just as in Canada. It requires extraordinary good will to escape the enmeshment of historic errors, misconceptions and misrepresentations and urgent need to correct the ensuing injustices that marginalize and demean, diminish and destroy the lives of too many Indigenous peoples. Irihapeti Ramsden's movement towards a model of Cultural Safety is a superb road map to places of unity and collaboration for decolonization as well as equity of access for all of Creation's diverse richness especially within the human diversity. She asked Moana Jackson to express the strengths of Cultural Safety in their sharing of reflective topical interviews (autobiographies). She records his narrative (Ramsden 2003:127):
First, its strength is to challenge students to analyze where they've come from. I don't think we should under-estimate that in New Zealand educational system because there is one thing that education lacks in this country, it is the teaching of an ability to be critical, the colonizing mentality doesn't encourage criticism, it encourages conformity. But what Cultural Safety as an academic idea does, is that it re-invents or reclaims the need to critically analyze things, and I think that's most important and its greatest strength in a general academic sense.

\begin{abstract}
In a more specific sense of nursing education, we as a people are not going to be able to remedy the unwellness of our people in six months or a year because it's the consequence of a hundred and fiftyseven years of dispossession. And so it's crucial that we have people working in that area who are actually going to help our people be well. And so, I think its strength is that it, it helps provide that in nursing education in a specific area. But then its broadest strength I think, is what we've been talking about a lot and that is, that a political idea and in the end remedying the ills of our people is a political and a constitutional issue, not in terms of the Beehive and Parliament, but in terms of changing the mindset of our people about our power and our powerlessness and so on. (Ramsden 2003 thesis chapter 9:2)
\end{abstract}

The above Indigenous worldview on the suffering of Indigenous populations from another colonial place requires a great deal of re-telling across Canada. Canada faces major challenges to its fragile confederation if it does not immediately address simmering Indigenous demands for a Fair Country (Saul, 2008). Saul (2008) in his book A Fair Country: Telling Truths About Canada, notes that Canada must revise how the meta-narratives of its colonial past form our collective identity. The very existence of this country beyond a colony requires accepting the contributions of many races (233). The collective soul of Canada according to Saul (2008) may be trapped in self-loathing, humiliation and false adoration because of our dependency on an identity flowing from British imperialism (243). John Ralston Saul on the subject of reconciliation highlights the growing contributions of Indigenous leaders:

Reconciliation can only happen if these concepts [Canadian identity from merely European influences] are based on truth-a truth that works for all people-and clarity of understanding between 
people. Guilt and pity, on the other hand, destroy human relations. Of course, these very real social problems were produced by the residential schools, the lack of respect for treaties, and the long period of institutionalized racism. These cannot be solved in an atmosphere of guilt and pity. The most basic need is to obtain knowledge and therefore understanding. There is a remarkable and fast-growing new Aboriginal leadership, which has a very good understanding of both Indigenous and non-Indigenous civilizations, such as how they fit together in their historic and modern forms and how they are influenced by each other. These leaders are finding new ways to be heard by their own communities and, also, by Canadians in general. This is happening because they are novelists, playwrights, lawyers, academics, and political figures. Their influence is growing incrementally and their understanding is key to breaking the old, intellectually lazy assumptions of most Canadians. The central need is not incremental; it is for a broad understanding of what change would look and feel like for everyone. (Saul 2009:313)

Saul's narrative endorses the work of Indigenous leaders like Irihapeti Ramsden who present ideas that can alter minds still clinging to the convenience of colonization. Those that cling continue to miss the disease that has resulted from the imposition of its Indian Act processes on First Nation, Métis, and Inuit worlds within the territory re-named Canada.

Ratinyenkehaka (Mohawk) Elder Jan Longboat (2009) teaches that Indigenous natural sovereignty has never been surrendered. She calls for Indigenous people to strengthen the spiritual ties to 'our place' and recover the 'richness' existing within traditional life-ways. Those are the ways that allowed us to feed ourselves, doctor ourselves, educate ourselves, and maintain disciplined just societies for hundreds of generations before the experience of imposed external domination by racist settler states. Jan Longboat (2009) claims we always had a richness that came from knowing how to plant gardens, hunt for sustenance, find the medicines we utilized for sustaining wellness and communicated in our beautiful languages. All of which made it possible to maintain and restore good will and address Creation with gratitude. Through these time proven practices our ancestors embedded the intergenerational worldviews and life-ways necessary for us to thrive in the places where we lived. We currently face a massive mourning challenge to recover from the historic intergenerational trauma colonization brought to Turtle Island [North America]. Jan Longboat defined 'poorness' in terms of elders identifying suffering people who had lost the richness of collective reciprocity and interdependence, who failed to follow culturally imperative teachings and the traditional skills necessary to provide a good life for themselves and their families. Promises of sharing, friendship and peace from faith in treaties never came true. Dispossession and dependency on hand-outs replaced efficacy and resilience. The loss of natural sovereignty meant citizens equipped with exceptional abilities to share beyond individual needs lost the ability to help in times of need and were replaced by Indian agents of tyranny and domination. Canada is needs a truth telling on the destructive impacts of Indian agents through the $18^{\text {th }}, 19^{\text {th }}$ and $20^{\text {th }}$ century to fully grasp the transfer of poverty from refugees to those seeking refuge from the atrocities of Canada's colonial history that paradoxically made reserves inhabitable remnants of Indigenous territories. The extreme circumstances of poverty in First Nations is a testament of stolen lands, stolen human rights to self-determination and stolen communities, or as Lee Maracle teaches "places we would want to stand under" (Maracle, 2009).

Indigenous scholars can now provide a culturally fair analysis of cultural adaptability and resilience, prompted by the forces of traumatic attacks through warfare, new diseases, land dispossession, forced assimilation and cultural genocide (Wesley-Esquimaux, 2004, Yellow Horse, 2004, Churchill, 1998). Attempts towards reconciliation over the national atrocities of residential schools, jails as reserves, and hate based identities that marginalized and sustained injustice is a hopeless ideal if Irihapeti Ramsden's Cultural Safety research is not enlivened through the teachings of our ancestors (Couture, 2002). Her thesis gives an excellent road map through what are mainly uncharted waters of tolerance and respect, especially when it comes to engaging, preparing and collaborating with Canadian change agents outside and inside Indigenous communities.

Irihapeti Ramsden (2003) chose to formulate her thesis as a reflective topical autobiography, a research writing method she attributes to Dr. Megan-Jane Johnston (1999), a nursing researcher interested in the "multiple realities and interpretations of lived experiences." Johnston (1999) draws on the work of Clark Moustakas who wrote on existential exploration through 'reflective topical account' narratives that could be compared with "other kinds of lives" narratives to explore and learn to express common experiences of human suffering. Self-research is an opportunity to revise and re-tell stories towards understanding the 'whole story' and leading to new consciousness and insights. I. M. Ramsden (2003) begins her self-exploratory reflective topical autobiography with a story of how her life-path led to the nursing profession. She wanted to find a way to maintain a family connection with her brother who had been sent to a boarding or residential school. A local nursing school offered such an opportunity for lodging and education as well as a way to visit her brother. Most Maori workers 
in the Wellington, New Zealand hospital where she trained were found in the kitchen, laundry, and garden or as orderlies (Ramsden, 2003:32). Her presence in a place of influence led to Irihapeti Ramsden becoming the trusting arbitrator between Maori patients and hospital staff negotiating for fairer access to services beyond the 'invisible boundaries of history and ideology' that feels like racism, classism and sexism. Irihapeti Ramsden looked to Paulo Freire's work who she credits for giving her a framework of understanding of the disregard for Indigenous human rights that infused colonial approaches:

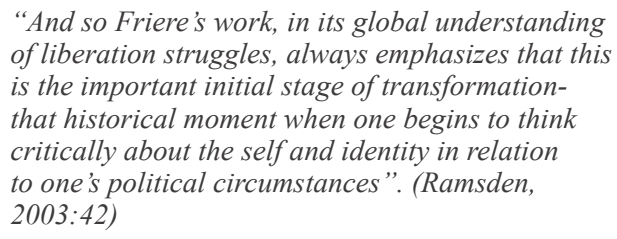

She sought an approach that would resist and rebel against entrenched ignorance and arrogance that sustains social, political and economic domination over Indigenous peoples and their traditional territories. The responsibility to end the silence of indifference and false innocence comes with awareness of the circumstances of the self and others:

\section{Human existence cannot be silent, nor can it be nourished by false words, but only by true words, with which men and women transform the world. To exist, humanly, is to name the world, to change $i t$. Once named the world in its turn reappears to the namers as a problem and requires of them a new naming. Human beings are not built in silence, but in word, in work, in action-reflection. But while to say the true word-which is work, which is praxis-is to transform the world, saying that word is not the privilege of some few persons, but the right of everyone. (Ramsden 2003:34)}

The Cultural Safety journey according to Irihapeti Ramsden (2003) also includes the, "ridicule, dismissal and marginalization" that comes from challenging conventional practice and perceived experts that avoid orientations requiring emotional or spiritual connections with "subjects" (180). It takes courage to engage others outside of the professional constraints that have created hierarchal expertise and power structures that eliminate humanism. This is paradoxical to Indigenous peoples who respect lived experience and ancient wisdom as vehicles to helping and healing their communities. Western practices often set up conflicting understandings and dismiss cultural needs instead of giving advice or pushing remedial interventions by experts. Irihapeti Ramsden (2003) laments that for Indigenous people this often looks and feels like racism. It allows for the transfer of misinformation both ways. The ensuing confusion often becomes painful and a ridiculous form of "dis-ease" making that eventually becomes politically charged. Irihapeti Ramsden wanted to understand the ensuing vicious circle caused by a pedagogy that maintains oppressive ways of interacting with marginalized and de-humanized patients.

The pathos, confusion and pathology that maintain Indigenous peoples' social, cultural and spiritual marginalization are evidence enough that forced assimilation has created historic trauma and unresolved grief across at least seven generations. In February of this year (2009), I sat in a graduate course at University of Toronto's Ontario Institute of Studies in Education (OISE) that ostensibly prepares future change agents across all cultures. The class is on community healing and peacebuilding and a fellow student asked for clarification on why Aboriginal people always talk about lessons from their ancestors, "Why can't they just move on to the here and now?" Fortunately, the instructor reminded the student that many Indigenous peoples globally follow the same cultural pattern of holding to traditional worldviews that embrace alternative paths of natural wellness and sovereignty. Jan Longboat (2009) provided a far superior teaching on this cultural misunderstanding, especially in relation to healing from our historical and traumatic experience of colonization. Jan Longboat suggests that Western mainstream culture is ignorant of the disruptions of the natural order of humans and of their home, Mother Earth. The concepts of past, present and future are held up as guides of progress and orientation. Modern culture seems to think that only scientific advances in the present can fix things, and if not, we can ignore suffering because there is always a heaven in the future. Jan Longboat (2009) reminds Indigenous survivors of historic trauma that our spiritual roles and responsibilities flow intergenerationally from seven generations back and forward and we must cherish the "blood memory" that ties us to what she calls the now, now and now. The word "now" is a loose English translation for Longhouse teachings on the roles and responsibilities that flow from ancestral cultural inheritances. Her Elders educated her, instructing her on why we are here, and clarified roles and responsibilities for good spiritual relationships. The three orders of instructions Jan Longboat highlighted as necessary for healthy communities are those for women and men, and for men and women that precede family responsibilities on how children can know their culture; all inclusive of men, women and children. The interference from and the resulting sickness from adopting foreign concepts of competitive and predatory interactions requires much more deliberation within our communities.

John Mohawk crafted a beautiful and eloquent Ph.D. thesis; A View from Turtle Island: Chapters in Iroquois Mythology, History and Culture. It contains a chapter titled "The Ancient Longhouse" where Mohawk (1994) 
offers powerful endorsements to an enduring womenspirit and the extensive roles and responsibilities women had to organize and orient Indigenous communities to communal harmony. The clan mothers and the older women of each communal longhouse controlled the sexual economy and negotiated marriages. They held the responsibility of preserving the land and the agricultural fields. Their role as overseers of the community development of the youth, including the young men, gave them the authority to manage the formation of healthy relationships. They knew the health of the men, their work habits and desirable qualities for ensuring longhouse cohesion. Violence, especially sexual violence carried severe sanction including possible death penalties, and therefore was rare. The coming of alcohol and cultural upheaval altered long held values and social order and created "mayhem and misery" in "gentle and loving communities" (Mohawk, 1994: 160). This is not a denial of intertribal conflict, the Iroquois Great Law established external conflict resolution processes which remain models of diplomacy and foster a respect for peaceful co-existence. Muller (2007) offers a remarkable history of the intent of the Haudenosaunee (Six Nations) people in the exchange of the non-interference Friendship Two Row Wampum. The belts which were to affirm the sovereignty of the Six Nations Confederacy internationally was described in the 1996 Canadian Royal Commission on Aboriginal People as "a model of parallelism with which to guide Canadian-Aboriginal relations" (Muller, 2007:152). It is important that we realign ourselves towards the reclamation of respectful existences that are not bound by poverty or powerlessness. Our present existence allows for insensitive inquisitors who want explanations on why we seek to disabuse ourselves of our pathological realities. These pathologies have become all too common images splashed across media, but traditional values continue to get little attention in learning spaces. Those spaces remain unprepared to accept Indigenous knowledge, and therefore our worldviews remain underrepresented and undervalued in academia. The lack of opportunity to address a wider audience and to inform new intellectuals with lessons from cultural informants like Irihapeti Ramsden, John Mohawk, Lee Maracle, Pauline Shirt and Jan Longboat is the greatest tragedy in post-colonial education. This loss makes the concept of Cultural Safety in Canadian higher education and workforce preparation somewhat premature. It makes modern social work, education, medical, legal, health and political schools of thought outdated, largely irrelevant, and in practice, dangerous for Indigenous peoples seeking refuge and recovery from colonial injustices. Canada faces an uncertain existential future and requires the incorporation of ideas like 'Cultural Safety' to reconcile the massive mistakes that have alienated First Peoples over the past seven generations. Irihapeti Ramsden (2003) and her students offer marvellous anecdotes to assisting in the evolution of the equitable society Canadians may be seeking. Crean (2009) in reviewing the lack of informing the public on the residential school era in Canada states:
Rarely do we connect the dots to see, for example, the pattern of governments resorting to the exclusion, discrimination, and exploitation of the disadvantaged and racially other. It started with the Indian Act, which was followed by the Chinese Head Tax, the Chinese Immigration Restriction Acts, and the Internment of Japanese Canadians. These are merely the highlights, for the list is long and the pattern is ingrained. Even with the Charter of Rights, equity laws could come and go, and no apology in the House of Commons, made to the sound of land claims stalling in the background, can atone for, much less change, the culture that produced the residential schools. That culture must take it upon itself to alter the stereotypes, correct the history, fill the gaps, or re-educate the public. What is the public to make of it anyway, given the government's continuing refusal to sign the United Nations' Declaration on the Rights of Indigenous Peoples? This confusion is symptomatic. The mixed signals are a product of a lack of leadership by non-Native elites and intellectuals and an absence of any real discourse in mainstream society. (Crean, 2009:63)

This paper honours the lessons of humility received from those with a strong women-spirit who gaze towards voices that get silenced all too often when shifting healing modalities and worlds collide (Little Bear, 2000). My loving, strong and generous Mohawk mother had a quiet firmness, and an endearing women-spirit who directed her children to always do what was right even the hardest choices. Even with the challenges of raising a family on a travelling carnival my mother modeled goodness and respect for everyone who engaged our family. It was not always easy and the internal as well as external stresses led to family violence. The struggle to maintain family cohesion is hard and solid life lessons came from her determination and devotion to the welfare of her children. Irihapeti Ramsden attributes her evolving notions of Cultural Safety to Megan-Jane Johnstone's (1999) paper, Reflective Topical Autobiography: an underutilized interpretive research method in nursing. These ideas represented here resonated strongly with an Indigenous man who has struggled to maintain loving, safe and peaceful relationships through five decades of not always simple living, feeling ashamed of a stigmatized identity and uncertain of the latent hostility deeply rooted in the strained colonial relationship between my peers. Johnstone (1999) wants social scientists to seek the invaluable personal narratives that inform and provide measures of wellness on all personal, social and emotional 
processes. Processes that in turn impacted intellectual and behavioural interventions for social scientists, calls reflective topical autobiography a vital tool that enables the self-researcher to:

$$
\begin{aligned}
& \quad . . \text { return at will to his or her life story again } \\
& \text { and again to re-read, re-vision and re-tell the } \\
& \text { story in light of new insights, understandings and } \\
& \text { interpretations of meanings acquired through } \\
& \text { ongoing lived experience. (1999:25) }
\end{aligned}
$$

Strong Indigenous women-spirit offers and supports crucial silence breaking and the physical, emotional, social, spiritual and political energy necessary to reinterpret the lived experiences of colonized peoples worldwide. The failure to teach on subjectivity in crosscultural community healing work becomes evident and problematic when such knowledge, or the lack of it, only surfaces in graduate studies. Indigenous scholars and Indigenous teachers know firsthand the ignorance and arrogance of Canadian citizens, especially the youth, who are allowed to make their way through educational institutions without preparation for engagement with Canadian First Nations people. This creates a double jeopardy for learning outcomes for both groups as neither First Nations scholars nor mainstream scholars get the Cultural Safety training necessary to navigate changing political realities in an increasingly postcolonial world. First Nations students struggle to stay in foreign, culturally unsafe institutions and non-Natives are unprepared to hear the stories coming in from 'Indian country.' Dominant culture students get a "rain check" on the obligation to establish a true reality check on a rapidly deteriorating Canadian/Indigenous relationship, all with global implications for national instability. The real irony is that Canada's First Peoples are gaining recognition outside this country as Indigenous pathfinders in social change, for their legal expertise on land claims, and knowledge about community healing in areas of violence, sexual abuse and addiction (Hodgson, 2008). Their knowledge and multiple skill sets would greatly serve Canadians wanting to do community healing social work at home or abroad where populations are struggling to heal from oppression, repression, state created poverty and political marginalization. Indigenous scholars must inform future generations in the Canadian social science workforce about divergent perspectives and help scholars shift from best practices to wise practices (Thoms, 2007).

Carolyn Ellis and Michael G. Flaherty (1992), in their book titled, Investigating Subjectivity, define subjectivity as "human lived experience and the physical, political, and historical context of that experience" (3). Ellis and Flaherty (1992) sought to bring to the attention of researchers the emotional baggage that accompanies all personal journeys of self-reflection. This inner journey is necessary to un-shelter thoughts and to reveal body reactions to the narratives held within each individual consciousness. Residential school narrative responses contain parallels to other human experiences of intergenerational historic trauma. Canadians generally stand to gain powerful insights into the spiritual, social, cultural, social, and political devastation the colonization of Turtle Island brought to First Nations people within Canada. These insights provide an honest reflection of the Canadian state and create a common experience for other victims of human suffering who now seek to share this bountiful refuge. Attempting to fix foreign colonization catastrophes seems paradoxical when Canadian governments avoid their own truths, responsibilities and obligations for reconciliation right here in our own backyard. Iripapeti Ramsden taught that Indigenous people must start within their homelands to get ready to assert collective natural sovereignty, and work together with allies who seek human justice and fairness. Jan Longboat echoes Ellis and Flaherty's (1992) invitation to reframe painful interpretative stories with "plurality, embracing the power of language to make new and different things possible" (5). This is because who we are is not limited to our suffering and we must seek the full dimensions of our experiences to locate and express blood memories of resilience and richness.

The cultural, historical and social confusion creates many difficult issues for teachers at all levels of education that must venture into the unresolved pain and injury of Canada's colonial past. Indigenous peoples are marginalized and invisible in most areas of study normally relegated to special programs like Aboriginal studies as if Indigenous world-views, knowledge, culture and vision for Canada's future required mere comma's in course material that feel like "oh yea, then there are aboriginal people who feel" that stand for inclusion but feel like after thoughts only if a visible "Indian" finds a seat in the class. Rauna Kuokkanen is a member of the Indigenous peoples of Norway and Finland, the Sami. Her research and work is in the area of colonial pedagogy and Indigenous studies. She is a guest lecturer at the University of Toronto in Aboriginal Studies and author of a must read book, Reshaping the University: Responsibility, Indigenous Epistemes[Worldviews] and the Logic of the Gift. Rauna Kuokkanen (2007) probes the lack of Indigenous perspectives, narratives and context in places that prepare Indigenous and non-Indigenous community helpers:

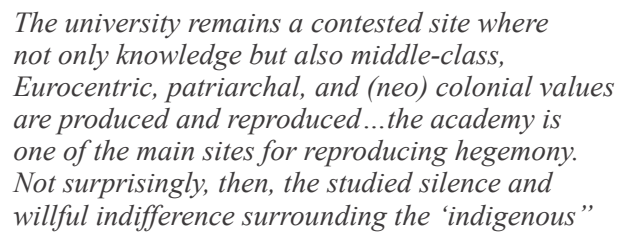

The university remains a contested site where not only knowledge but also middle-class, Eurocentric, patriarchal, and (neo) colonial values are produced and reproduced...the academy is one of the main sites for reproducing hegemony. Not surprisingly, then, the studied silence and willful indifference surrounding the 'indigenous" 


\section{Irihapeti Ramsden: The Public Narrative on Cultural Safety}

continues unabated in most academic circles. In the same way that indigenous peoples (and their epistemes[worldviews]) remain invisible when the nation-states were shaped, indigenous scholarship remains invisible and unreflected in most academic discourses, including that of some of the most progressive intellectuals. (Kuokkanen, 2007:156)

Neal McLeod (2007) credits Smith Atimoyoo, one of the founders of the Saskatchewan Indian Cultural College for teaching Indigenous people to use "new arrows", "words that can be shot at the narratives of the colonial power" (McLeod, 2007). McLeod (2007) in a genre creating book Cree Narrative Memory: From Treaties to Contemporary Times, demonstrates the cultural revitalization of "coming home through stories" where past and present stories allow the cultural transmission of the struggles to retain human dignity in the face of colonial dispossession, devastation and humiliation. He re-locates a story on "damn lazy Indians:"

\begin{abstract}
A long time ago, an old man and his grandson went to town. The boy was about fourteen. They had gone to town to by groceries. They milled about the store and collected the items that they needed. After they filled their cart, there was a man by door. He said to his friend, "Damn lazy Indians." The man then went up to the old man and said, "You are god-damn lazy. Why can't you just stay on the reserve, where you belong?" The taunts continued, but the old man kept calm. After they gathered their groceries, they stood outside their vehicles. The grandson asked, "nimosom, why didn't you say something to that man who was there, who was saying those things to us?" The grandfather answered his grandson with another question:

"How long were we in the store?"

"Well, we were there for five minutes."

"Yes, my grandson. We were in that store for five minutes. We had to deal with that man for five minutes. But he has to deal with himself for the rest of his life" (McLeod, 2007:68-69).
\end{abstract}

Pattakos (2008) in his book Prisoners of our Thoughts reflects on Viktor Frankl's principles for discovering meaning in life and work reminding his readers that people do find reasons to live in the most horrendous of circumstances and we must not be prisoners of self-defeating and self-destructive thoughts. Viktor Frankl another $20^{\text {th }}$ century survivor of one of man's most intentional evils, the Holocaust, found numerous stories of enduring humanity in the face of the kind of destruction that must always be remembered in order to give true meaning to life. Viktor Frankl devoted his post Nazi concentration camp survival period to re-write the meaning of life in the most horrendous circumstances. Transformation and transcendence is possible when a conscious choice to reclaim a good life with a good heart and good mind. Young people especially need Cultural Safety in learning to re-tell, revise and restore traditional wisdom to navigate the despair, helplessness and hopelessness they see in their communities. History is tragically repetitive and like the fourteen year old youth humiliated by the maltreatment of his grandfather in a Prairie grocery store it is Canada's Indigenous youth who remain the most disillusioned with Canada. The tragic life trajectory to become successful stereotypes of lazy, drunken, suicidal, gang affiliated, incarcerated and militant "damn Indians" is an all too common experience for these youth (Koptie, 2009). Pattakos (2008) offers the following story; "The Echo" to remind us of our engagement with our youth world in the ways they choose to interact with their world:
A son and his father are walking in the mountains. Suddenly, the son falls, hurts himself, and screams" "AAAhhhhhhhh!!!" To his surprise, he hears a voice repeating, somewhere in the Curious, he yells out: "Who are you?" And he screams to the mountain: "I admire you!" The voice answers: "I admire you!" Angered at the response, he screams: "Coward!" He receives the answer: "Coward!" He looks to his father and asks: "What's going on?" The father smiles and says: "My son, pay attention." Again, the man screams: "You are a champion!" The boy is surprised, but does not understand. Then the father explains: "People call this ECHO, but really this is LIFE. It gives you back everything you say or do. Our life is simply a reflection of our actions. If you want more love in the world, create more love in your heart...Life will give you back everything you have given to it. Your life is not a coincidence. It's a reflection of you!

This follows a style of Indigenous knowledge transfer that the Cree Elder in the above story as well as Jan Longboat, John Mohawk and Irihapeti Ramsden and my mother Iris Grace (Lickers) Koptie. Lee Maracle and Pauline Shirt advocate restoring collective Indigenous social, economic, spiritual and political self-determination narratives and heal the deep collective wounds of colonization.

As we look to the west to spaces and places in the Pacific like New Zealand for road maps through colonization to post-colonial sovereignty we can also look to Hawai'i and teachings from Poka Laenui (2000). Both the Hawai'i State legislature and the United States Congress have admitted to the illegality of the overthrow of the Hawaiian nation, (Laenui, 2000). President Clinton in 1993 oversaw a "Joint Resolution of Apology" by both political bodies to begin a legacy of reconciliation that marks a dramatic shift from denial towards post-colonial reparations for past wrongs. Laenui (2000) has created 
crucial points of convergence for Indigenous scholars to review and articulate reflective topical autobiographies being shared by Indigenous peoples throughout Mother Earth. The common experiences of social, cultural, and spiritual devastation to create plunder zones (Maracle, 2009), is the real narrative of mythical lies about modernization and civilization (Trudell, 2004). Laenui (2000) invites all scholars to research the late Philippine social scientist Virgilio Enriques who called for the restoration of the integrity of Indigenous wisdom. Laenui (2000) tracts the process of colonization through five stages: Denial and Withdrawal, Destruction/Eradication, Denigration/Belittlement /Insult, Surface Accommodation/ Tokenism and Transformation/Exploitation, (Battiste, 2000: 150-152)

European settlers still cling to the myths of discovery, entitlement, prerogative power and racial superiority that foster the denial of the very existence of a vibrant culture among Indigenous people. Where interdependency developed, it was assumed Indigenous groups would yield their own cultural practices, yet the majority of Indigenous groups actually resisted imposed dependency for the sake of self-preservation and to protect their traditional life-ways. A battle for conversion began with the imposition of colonization. This rush of religions to replace what they deemed "devil worship" with a new spiritually, and medical experts for the "witch doctors" they despised, criminalizing traditional ceremonies and practices, and reducing Indigenous peoples' cultural structures to ignorant superstitions, set up cultural warfare where arrogance replaced Cultural Safety with ignorance.

My experience of going back to graduate school after close to 30 years of community work mostly in First Nations communities has been a 'Dickenish' tale. It is a tale of two existential extremes the best of times and the worst of times mostly simultaneously as each glorious lesson learned carries the lonely burden of responsibility to challenge the shame and humiliation of each racist, ignorant and arrogant lesson taught. Like Oliver Twist we want more. Cook-Lynn (2007) addresses this paradox in her important work Anti-Indianism in Modern America: Voice from Tatekeya's Earth, where she write about the obligation to project voice to people who "believe in the stereotypical assumption that Indians are 'damned,' vanished, or pathetic remnants of a race" and "lets get rid of Indian reservations" or "lets abrogate Indian treaties." Instead of feeling inspired to find a place of good will far too much energy is sapped escaping spaces of intentional indifference. Times are changing rapidly especially racial realities in North America. The invisibility of Indigenous peoples can not continue and President Obama has enlivened the truth and reconciliation debate across Turtle Island [North America]. Indigenous people look for transformative signs of hope in the son of the civil rights struggle for African decedents of slavery. Barak Obama's ascension to power again changes America's place in the $21^{\text {st }}$ century for all humanity. His pledge to re-visit America's obstruction and non-endorsement of the United Nations Declaration on the Rights of Indigenous Peoples follows Australia and New Zealand change of heart on their colonial pasts leaving Canada the lone hold-out of denial and shameful conduct to reconcile its history based on the Doctrine of Discovery, the sad rationalization to maintain prerogative power and domination over its Indigenous peoples' lands and resources.

The national Episcopal Church of America during its July $200976^{\text {th }}$ General Convention in Anaheim, California passed a groundbreaking landmark resolution repudiating the validity of the Christian Doctrine of Discovery that led to the colonizing dispossession of the lands of Indigenous peoples around the planet. The Church also called on Queen Elizabeth II to "disavow, and repudiate publicly, the validity of the Christian Doctrine of Discovery," (Miller, 2009). Miller (2009) poses a long overdue paradigm shift to re-tell, review and re-negotiate notions of prerogative power myths that permeate so many social structures of race, culture, gender and religion that mark the paternalistic guardian/ward relationships within the "Promise Land":

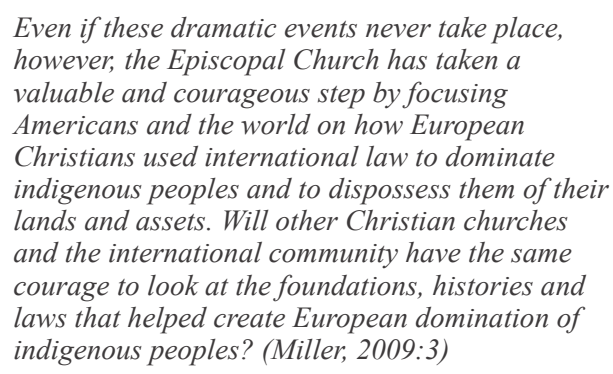

When western intrusions and assimilation practices generate resistance and rebellion, some form of accommodation was necessary to make the process more palpable to the reluctant colonized. Treaties became the conduit of colonization and Irihapeti Ramsden's journey to a cross cultural theory on Cultural Safety required reflecting on the New Zealand Treaty of Waitangi which follows the pattern of settlement arrangements between Indigenous peoples and settlers of all British colonies worldwide including Canada. There have always been those with keener insights on historical inertia. Indigenous scholars are gaining recognitions as experts on this phenomenon. Laenui (2000) calls this cultural tokenism disingenuous as the intent remains the eradication of Indigenous identity. The final phase of transformation and exploitation is best understood when we look to early $21^{\text {st }}$ century second thoughts about the colonization project by First Nations across Canada. Canadians must begin 
to question disturbing aspects of the social decline of their Indigenous wards of state by way of Indian treaties and support calls for a national political renaissance. Indigenous cultures are a natural part of Canada's modern identity. All Canadians need to escape Victorian Age British imperialism that lingers through the Canadian Indian Act which upholds Canada's treaty relationship for all Canadians. On the ground it is always the women and children who suffer the greatest impacts.

In January 2009 I pleaded with a group of water rights activists on their way to initiate legal challenges to stop the oil sands disaster, to first watch Alanis Obomsawin's powerful National Film Board (1986) documentary, Richard Cardinal: Cry form a Diary of a Metis Child, a re-telling of the horrific, tragic and fatal experience of Richard Cardinal who committed suicide from within the Alberta child welfare bureaucracy. He killed himself at age 17 after the trauma of being shunted through 28 foster homes, group homes and shelters (National Film Board 2009). I used this documentary to train college social services students at George Brown College in Toronto about Cultural Safety in social work practice. It is set in Fort Chippewa First Nation in northern Alberta and is a true depiction of the human ravages of colonization. Hundreds of birds drowning in poisoned oil tailing ponds are recent disturbing images that garner a great deal of national and international outrage. Rarely does the Canadian public witness the true human impact of their privileged society's greed for the stuff needed for unsustainable progress located mostly in Indigenous homelands. For generations Alberta's Indigenous people have witnessed the destruction, plundering and disregard for all creation on Mother Earth, including human. Alanis Obomsawin's (1986) film is an on the ground testimony of the legacies that follow the loss of Indigenous natural sovereignty to maintain and protect the lands and future generations of their ancestors. What happens when a people lose the most fundamental purpose of their lives to exist with seven generations in good minds? The limited attention span of the dominant culture calls for a greater distribution of Jan Longboat's teachings on NOW/NOW and NOW. Jan Longboat (2009) is clear that to survive seven generations ahead we as Indigenous people must not linger in the traumas of our pasts, not fear our future and not live in the present as if we had no past or will have no future. Our recovery is finding our way in the NOW. The disregard of nurturing and healing women-spirit is tearing at our collective souls and creating wounds that may never heal (Duran, 2006). De-colonizing requires reactivating that life force that women have always known. They are the protectors of water and the traditional teachings on water must be re-located. We all enter the living world through our mothers' water.
Laenui (2000) presents five processes for Indigenous decolonization: Rediscovery and Recovery, Mourning, Dreaming, and Action. These phases are interchangeable and follow various combinations. They provide a healing model most Indigenous helpers recognize. Ramsden (2003) and Longboat (2009) use their powerful women-spirit to mentor the use of reflective topical autobiographies and narratives within this framework and to offer on the ground practical community healing through trained and informed key workers.

The rediscovery of a positive Indigenous identity, the stopping of suffering based on ridiculous concepts of inferiority in the face of constant ignorance and arrogance that prop up colonial lies of superiority by settlers, is vital to begin a journey towards recovery. This journey may seem overwhelming for beaten down victims of violence. The roots of violence come from all forms of violation that impede human freedom and impede a just humanity up to crimes against humanity. Canada's choice of residential schools as a tool to "de-Indianize" Aboriginal peoples will soon be a global marker for future generations on the evils of state abuse of power and human rights. The intentional denial or limitation of human rights protection for all citizens contravenes the ultimate indicator of good governance and legitimate sovereignty. Failure to act is symptomatic of failed states. If we continue to see painful images in our mirrors of identity, we cannot forget to reverse that mirror so all Canadians have to challenge the images of political, social, economic, judicial injustices. Then as Saul (2008) proposes, the people of Canada can join First Nations people in a mourning of the victimization that followed colonization. "I didn't know" is a frequent pronouncement in the face of unawareness of suffering and pain, but this statement needs to precede "I am sorry." Genuine remorse comes through the honesty and courage to face the wrong and declare "NEVER AGAIN!" Indigenous victims can then be helped to transcend the "awfulizing" that is the result of mourning (Laenui, 2000) and begin a transformative journey from "victimization" through "survivorship" to "victorization" (Wesley-Esquimaux, 2007).

Dreaming is the stage of decolonization that offers the buried remnants of ancestral blood memory (Longboat, 2009). Longboat (2009) calls our dreams a spiritual mirror. She teaches that colonization has been a heavy burden on our spirits. Jan Longboat through her wry humour tells how science is finally catching up with Indigenous wisdom. Science informs us that we may have 30,000 thoughts in any given day and that the ensuing confusion that comes from undisciplined thinking can cause much stress in modern day to day living. Indigenous healers were traditionally advised to meditate on the messages in dreams as guides to fulfilling roles 
and responsibilities "before your feet hit the ground." Jan Longboat teaches that winter time is a time of sharing narratives from those dreams to articulate the collective unconscious of all communities and to plan a way forward that follows ancestral wisdom coming from our ancient sense of place and time. The humble way forward has always come from the way we chose to engage the magnificence of Creation. Dreams create path-ways for knowing how we are doing. This was true prior to the onslaught of colonial interference that now creates thousands of troubling thoughts. Remember the above EHCO story. The final stage of action comes through understanding; "WHAT IS OUR NOW?"

Irihapeti Ramsden's devotion and remarkable legacy to carry out her role as a life nurturer with enduring women-spirit remains a powerful role model to all who struggle to maintain a distinct Indigenous identity. Her approach must be further studied and emulated by Indigenous scholars. We honour her spirit of service by following her path. Although we may become tired in our struggles to transform the structures of governance that cripple our communities, we are part of a resistance and rebellion against the fracturing of our civil societies. Natural sovereignty, alongside political and judicial processes helps to maintain order and foster a natural interdependency and reciprocity that will economically sustain our right to self-determination of our future on Turtle Island. After studying the journey of reclamation written in Irihapeti Ramsden's doctoral thesis I remain humbled by her struggle. She was able to inspire an entire population of Indigenous peoples to redefine themselves in their ancestor's original image and the legacy of treaty violations on all citizens. Key elements of her thesis and work must be transmitted across Canada as a invitation to explore tarnished Canadian treaty relationships and their implications for future wellness for all Canadians. We will return once more to her mentor Moana Jackson for a narrative of inspiration;

...In a general New Zealand sense, to teach de-
colonization you have to teach history, you have to
teach the ideas and philosophies of dispossession.
And in nursing, as part of the culture, there is a
need for it as well. So to have a de-colonized nurse
requires the teaching of all the things Cultural
Safety tries to do.
... I actually see that the treaty has be recaptured
and redefined and tin rangatiratanga [good
leadership] has been redefined because the treaty
has been redefined and if the treaty is to be part of
Cultural Safety, then it has to be seen for what it is,
that is a colonizing text. It was, in the eyes of the
colonizers, a tool to facilitate our dispossession.
Now that's not how it was seen by our tipuna
[ancestors] and I think both sides need to be seen
and understood and again, if you have a culturally

(C) Steve Koptie safe nurse they need to understand both sides. But what happens is, because of the redefinition that's taken place, if two sides are taught, it's the Crown side and the Crown version of the Maori side so they're still getting the treaty as a colonizing text. They're not getting the treaty as a reaffirmation of Maori rights, but the treaty as a colonizing text, then it has no part in Cultural Safety. If it is seen as a colonizing text in the eyes of the Crown but as an affirmation of our independence, in the eyes of our people, then it has to be part of the history and the background that Cultural Safety seeks to address. I get increasingly disheartened when I hear our people talk about our rights as if they begun on the $6^{\text {th }}$ February 1840, as if prior to that we were right-less. As though we didn't have a process that defined who we were, what our rights were what our obligations were and so on ... But the treaty is not the reason for Cultural Safety, colonization is the reason for Cultural Safety and therefore the treaty is part of the colonization story. If there'd been no treaty, our rights would still be there, and what I think is important to do is to place it firmly in that context. (Ramsden 2003:127-128)

Irihapeti Ramsden's work on Cultural Safety is a path-way to collaborative de-colonization and an invitation for all humanity to grow in understanding and unity. Canada is approaching a place in our history where her journey can guide the truth and reconciliation experience which could in turn, transform a colony into a nation. Since starting this writing project I have shared numerous copies of her Cultural Safety thesis as an expression of an excellent narrative creation and worldview that can be disseminated across diverse disciplines beyond nursing and teaching. Irihapeti Ramsden's Cultural Safety legacy is truly a gift as Kuokkanen (2007) invites us to re-locate and re-enliven from Indigenous worldviews:

Instead of viewing the gift as a form of exchange or having only an economic function, I argue that the gift is a reflection of a particular worldview, one characterized by the perception that the natural environment is a living entity which gives its gifts and abundance to people provided that they observe certain responsibilities and provided that those people treat it with respect and gratitude. Central to this perception is that the world as a whole comprises an infinite web of relationships, which extend and are incorporated into the entire social condition of the individual. Social ties apply to everyone and everything, including the land, which is considered a living conscious entity. People are related to their physical and natural surroundings through their genealogies, their oral traditions, and their personal and collective experiences with certain locations. Interrelatedness is also reflected in many indigenous peoples' systems of knowledge. These systems are commonly 


\section{Irihapeti Ramsden: The Public Narrative on Cultural Safety}

explained in terms of relations and are arranged in a circular format that consists mainly (if not solely) of sets of relationships whose purpose is to explain phenomena. In many of these systems of knowledge, concepts do not stand alone; rather, they are constituted of "the elements of other ideas to which they were related." (Kuokkanen, 2007:32)

\section{Bibliography:}

Arnold, K (2007). Domestic War: Locke's Concept of Prerogative and Implications for U.S. Wars Today, Polity (39), 1-28. Available at http://www.palgrave-journals.com/polity.

Blaser, M., Feit, H. \& McRae, G. (2004). In the Way of Development: Indigenous Peoples, Life Projects and Globalization, located at http://www.idrc.ca/en/ev-58137-201-1-DO_TOPIC.html.

Churchill, Ward (1998). A Little Matter of Genocide: Holocaust and Denial in the Americas 1492 to the Present. Winnipeg, MB: Arbeiter Ring Publishing.

Cook-Lynn, E. (2001). Anti-Indianism in Modern America: a voice from Tatekeya's Earth. Chicago, IL: University of Illinois Press.

Couture, Joseph (2002). Indigenous Knowledge in the Academy, " in Indigenous Knowledge in Global Context: Multiple Readings of Our World, George J Sefa Dei et al (Eds.). Toronto, ON: University of Toronto Press.

Crean, S. (2009). Both Sides Now: Designing White Men and the Other side of History. In Response, Responsibility, and Renewal: Canada's Truth and Reconciliation Journey, Younging, G., Dewar, J., and DeGagne, M. (Eds.). Ottawa, ON: Dollco Printing.

Duran, Eduardo (2006). Healing the Soul Wound: Counseling with American Indians and other Native Peoples. New York, NY: Teachers College Press, Columbia University.

Durie, M. (2009). Indigenous Health Workforce Development: Maori Experience, paper delivered at First Nations Health Managers Second National Conference. Vancouver, BC.

Ellis, C. \& Flaherty, M. (1992). Investigating Subjectivity, Newbury Park, CA: Sage Publications.

Ellison-Loschmann, L. (2003). Irihapeti Ramsden: Obituary, located: http://culturalsafety.massey.ac.nz/.

Hodgson, M. (2008). Personal reflection on the Healing Our Spirit Worldwide Conference to be held in Hawaii, September 3-10, 2010.

Johnstone, M. (1999). Reflective topical autobiography: an underutilized interpretive research method in nursing. Collegian, Vol. 6 (1).

Koptie, S. (2009). Metaphoric Reflections on the Colonial Circus of the Drunken Indian and the Kidney Machine. First Peoples Child and Family Review, 4(1), 66-79.

Kuokkanen, R. (2007). Reshaping The University: Responsibility, Indigenous Epistemes, and the Logic of the Gift. Vancouver, BC: University of British Columbia Press.
Little Bear, Leroy (2000). Jagged Worlds Colliding, in Reclaiming Indigenous Voice and Vision. Vancouver, BC: UBC Press.

Laenui, P. (2000). Processes of Decolonization. In Reclaiming Indigenous Voice and Vision, Battiste, M. (Ed.).Vancouver, BC: University of British Columbia Press.

Longboat, J. (2009). Traditional Teaching: "How to Create Healthy Dreams and Healthy Dreams," at Queen's University, $10^{\text {th }}$ Annual Aboriginal Symposium: "Spirituality", January 24, 2009.

Macklem, Patrick (2001). Indigenous Difference and the Constitution of Canada. Toronto, ON: University of Toronto.

Maracle, Lee (2009). Lectures: Indigenous Writing. SAGE, University of Toronto, Ontario.

McLeod, N. (2007). Cree Narrative Memory: From Treaties to Contemporary Times. Saskatoon, SK: Purich Publishing.

Mitchell (Kanentakeron), M. (1984). Traditional Teachings. Cornwall Island. On: North American Indian Travelling College.

Miller, R. (2009). "Miller: Will others follow Episcopal Church's lead?" Indian Country Today, August 9, 2009. Online: http://www.indiancountrytoday.com/internal?st=pri nt\&id $=52646107 \&$ path $=/$ archive .

Mohawk, J. (1994). A View From Turtle Island: Chapters in Iroquois Mythology, History and Culture. Buffalo, NY: University of New York at Buffalo.

Muller, K. (2007). The Two ‘Mystery' Belts of Grand River: A Biography of the Two Row Wampum and the Friendship Belt. American Indian Quarterly,31:129-64.

Obomsawin, A. (1986). Richard Cardinal: Cry from a Diary of a Metis Child, film by National Film Board of Canada.

Pattakos, A. (2008). Prisoners of Our Thoughts: Viktor Frankl's Principles at Work. San Francisco, CA: Barrett-Koehler Publishing.

Rae, H. \& Katz, E. (2007). Trudel: The Movie, Boise, ID: Appaloosa Pictures and Balcony Releasing.

Ramsden, I. (2003). Cultural Safety and Nursing Education in Aotearoa and Te Waipounamu. Doctoral Thesis, located: http://culturalsafety.massey.ac.nz/.

Saul, J. (2008). A Fair Country: Telling Truths About Canada. Toronto, ON: Viking Canada.

Saul, J. (2009). Reconciliation: Four Barriers to Paradigm Shifting. In Response, Responsibility, and Renewal: Canada's Truth and Reconciliation Journey, Younging, G., Dewar, J., and DeGagne, M. (Eds.). Ottawa, ON: Dollco Printing.

Shirt, P. (2009). Lectures: Indigenous Writing. SAGE, University of Toronto, Ontario.

Thoms, M. J. (2007). Leading an Extraordinary Life: Wise Practices for an HIV Prevention Campaign with Two-Spirit Men. Prepared for 2 Spirited People of the First Nations: Toronto.

Wesley-Esquimaux, C. \& Smolewski, M. (2004). Historic Trauma and Aboriginal Healing, Aboriginal Healing Foundation. Ottawa, ON: Dollco Printing. 
Wesley-Esquimaux, C. (2009). Trauma to Resilience: Notes on Decolonization. In Restoring the Balance: First Nations Women, Community, and Culture, Valaskakis, G. and Stout, M., and Guimond, E. (Eds.). Winnipeg, MB: University of Manitoba Press.

Yellow Horse-Brave Heart, M. (2004). the Historical Trauma response among natives and Its relationship with substance abuse: A Lakota illustration, in Nebelkopf, E. and Phillips, M. (Eds.). Healing and Mental Health for Native Americans: Speaking in Red. 